\title{
The Effect of Full Day School Implementation on Learning Motivation of Elementary School Students
}

\author{
Yantoro ${ }^{1 *}$, Mohamad Muspawi ${ }^{2}$, Shalahudin ${ }^{3}$ \\ 1,2,3 Faculry of Teaching and Education, Universitas Jambi, Jambi, Indonesia \\ *e-mail: yantoro@unja.ac.id
}

\begin{abstract}
This study aims to analyze an effect of the implementation of full day school on learning motivation of elementary school students. The research method used is a mixed research method with explanatory design. The number of samples used were 174 students. The research data were obtained by distributing a full day school application questionnaire and a student learning motivation questionnaire, as well as conducting interviews with students. Furthermore, the data were analyzed quantitatively with simple regression type and inferential statistics. The results showed that has been done, it can be concluded that the implementation of full day and student motivation in Elementary School is already in a good category. This is reinforced by the results of interviews which show that through the implementation of full day school it can have a positive impact, namely that student creativity can be more developed, achievement increases, and students can develop their talents and skills through extracurricular activities, which can then be developed. Make it easier for teachers to deliver material to students because of the time. which is old. Based on the hypothesis test conducted, it was found that there was an influence between the implementation of full day school on student learning motivation in elementary schools, with the percentage contribution of the influence of $61.3 \%$ to the dependent variable, and $39.7 \%$ influenced by other variables.
\end{abstract}

Keywords: Elementary School, Full Day School, Learning Motivation

\section{Introduction}

Education is one of the areas that is strategic enough to be used as a vehicle for the development of superior and character human resources (Islami et al., 2015). With human education, it can change behavior and knowledge for the better (Astalini. et al., 2019). Education plays an active role in improving the quality and quantity of human resources (Darmaji. et al., 2018). Efforts that can be made in the field of education to produce quality human resources can be done by getting used to forming a culture of critical thinking in students in the learning process (Antara et al., 2020; Fujika et al., 2015). To improve the quality of education in Indonesia, it must also be supported by the quality of its education personnel (Asrial. et al., 2019). Teacher competence is one of the important factors that determine the success of the learning process. The learning process is an activity designed to help someone learn a new ability or value (König et al., 2020). Learning is the process of getting information and values in a system management (Darussyamsu et al., 2019). This information can be in the form of ideas, ideas, science that is packaged in an interesting way so that students are interested in learning and are active in seeking answers to all the problems they face (Budiarati \& Sadikin, 2015).

There are various ways that can be used to improve the quality of education, for example by implementing a full day school learning system. Full Day School comes from English which consists of three words. Full day school literally means a full day at school (Sari et al., 2017). In addition, in broad terms full day school has the meaning of education that implements learning that adds lesson hours to deepen learning material so that students can develop creativity and self-development. In full day school, learning activities such as school assignments that are usually done at home can be done at school under the guidance of the teacher on duty. However, it does not mean that full day school restricts students from

\footnotetext{
${ }^{*}$ Corresponding author.
}

Received February 19, 2021; Accepted April 10, 2021; Available online September 25, 2021

Copyright $@ 2021$ by Author. Published by Universitas Pendidikan Ganesha. 
playing and continues to learn, but in full day school there are also learning methods and media that cover class and nature so that students do not become bored. With the full day school system, the length of learning time is not a burden because part of the time is used for informal times (Soapatty, 2014).

In the learning process, learning motivation is needed by students as subjects who do learning. Without motivation, a person will not be able to take action to learn, because his activities for learning will not occur without strong motivation. In general, motivation means something that encourages action or action (Sunaryo, 2014). Motivation can be defined as the strength (energy) of a person which can lead to a level of persistence and enthusiasm in carrying out an activity, both from within the individual (intrinsic motivation) (Albrecht \& Karabenick, 2018; Ifinedo, 2016; Moozeh et al., 2019; Ryan \& Deci, 2020). For example, students have their own will to learn physics, are able and concentrate while studying physics (Riswanto \& Aryani, 2017). And from outside the individual (extrinsic motivation). Like getting prizes and getting good grades. Furthermore, motivation is a change in energy in a person's (personal) self which is marked by the emergence of feelings and reactions to achieve goals (Gopalan et al., 2017; Ibrahim \& Nat, 2019; Khan et al., 2019; Puspitarini \& Hanif, 2017). Motivation to learn arises due to the high curiosity in students and the desire to be able to understand something as well as the urge to direct interest in learning so that students are serious in achieving achievement. In the learning process motivation has a very important role for students because it can provide stimulus, enthusiasm, and a sense of joy in students (Wahyuni et al., 2018; Wardani et al., 2020).

In Jambi City, there are many educational institutions that have implemented a full day school system, one of which is Elementary School 47 / IV in Jambi City. The existence of a full day school can be seen from the curriculum used by the school which is different from other schools. With the implementation of this full day school, it is hoped that student achievement will increase both in academic and non-academic fields. Based on the observations that have been made, the researchers found problems or impacts arising from the implementation of the full day school system, one of which is that students often come and go during class hours. Then the condition of students who are tired and tired so that it can interfere with the concentration of learning of students. Because the condition of tired students causes students to be less enthusiastic in learning, there are students who are sleepy during the learning process, students prefer to tell their friends behind the class instead of listening to the teacher explain. In connection with the implementation of the Full Day School system, especially in schools Elementary 47 / IV Jambi City, it is necessary to conduct research on the effect of the implementation of the Full Day School system on student motivation in elementary schools. It is hoped that the results can be used as a reference for further research or can be a guide for teachers to make the learning process more interesting and not boring so that students are more motivated to participate in teaching and learning activities. This study aims to analyze the effect of implementing the full day school system on student learning motivation in elementary schools and to describe the implementation of full day school and student learning motivation.

\section{Method}

The type of research and design used are mix method research using explanatory design. Explanatory design is a research design in mixed research characterized by the collection and analysis of quantitative data in the first phase followed by the collection and analysis of quantitative data in the second phase which is built on the initial quantitative results (Cresswell, 2012). The variables in this study used 2 variables, namely the independent variable and the dependent variable. The independent variable in this study is the application of full day school, while the dependent variable in this study is learning motivation. The sample in this study using purposive sampling technique. The reason for using purposive sampling technique is because not all samples have criteria that match the phenomenon under study. Therefore, the authors chose a purposive sampling technique that determines certain considerations or criteria that must be met by the samples used in this 
study. The sample used in this study, 174 students from Elementary School 47 / IV Jambi City. The instrument in this study used 2 types of instruments, namely a full day school application questionnaire and a learning motivation questionnaire and documentation. Where the full day school used adapted from Al-Qurni's research, and the learning questionnaire motivation was adapted from research conducted by Aryani (Al-Qurni, 2019; Aryani, 2019). The following is the lattice for the learning motivation questionnaire instrument in Table 1. The categories used in this study for full day school application instruments are presented in Table 2.

Tabel 1. Category of Learning Motivation

\begin{tabular}{lll}
\hline \multicolumn{1}{c}{ Interval } & & Kategori \\
\hline $45,0-81,0$ & Very not good & \\
$82,0-117,0$ & Not good & \\
$118,0-153,0$ & Enough & \\
$154,0-189,0$ & Good & \\
$190,0-225,0$ & Very good & \\
\hline
\end{tabular}

Tabel 2. Category of Implementation full day school

\begin{tabular}{lll}
\hline \multicolumn{1}{c}{ Interval } & Kategori \\
\hline $30,0-54,0$ & Very not good & \\
$55,0-78,0$ & Not good & \\
$79,0-102,0$ & Enough & \\
$103,0-126,0$ & Good & \\
$127,0-150,0$ & Very good \\
\hline
\end{tabular}

Furthermore, the instrument used is documentation. The documentation obtained is in the form of photos during the activity. It is intended to be used as an additional reference in research. The documentation in this study is used as supporting data from the results of data analysis later. In addition, researchers also use interviews as data that strengthen the results of the data descriptions. In conducting the data, the first activity that must be done is selecting students based on the categories given by the researcher, then giving an emotional intelligence questionnaire to students, then conducting semi-structured interviews to ensure the quantitative results that have been carried out. Then the questionnaire data was processed using the SPSS 23 application to see descriptive statistics, in the form of mean, min, max, percentage, and student categories, while for qualitative data using Miles \& Huberman, namely data reduction, data presentation, and conclusion

\section{Result and Discussion}

\section{Results}

Results are the main part of scientific articles, containing: final results without data analysis process, hypothesis testing results. Results can be presented with tables or graphs, to clarify the results verbally.

Tabel 3. Results of implementation full day school

\begin{tabular}{|c|c|c|c|c|c|c|}
\hline \multicolumn{3}{|c|}{ Classification } & \multirow{2}{*}{$\%$} & \multirow{2}{*}{ Min } & \multirow{2}{*}{ Max } & \multirow{2}{*}{ Mean } \\
\hline Range & Category & Freq & & & & \\
\hline $30,0-54,0$ & Very not good & 0 & 0 & & & \\
\hline $55,0-78,0$ & Not good & 0 & 0 & & & \\
\hline $79,0-102,0$ & Enough & 47 & 27 & 79 & 110 & 103,86 \\
\hline $103,0-126,0$ & Good & 127 & 73 & & & \\
\hline $127,0-150,0$ & Very good & 0 & 0 & & & \\
\hline
\end{tabular}


Based on Table 3, it is known that as many as $73 \%$ (127 of 174) students are in the good category with a maximum score of all statements on the variable implementation of full day school 110, and the minimum score obtained by students is 79 . This shows that most students feel that with full day school has a good impact or influence on learning activities at school. Then there were $27 \%$ (47 of 174) students who were categorized as sufficient, which means that students were still confused about the benefits of implementing full day school for learning activities, they still could not distinguish how the difference was before and after the implementation of the full day school system. The average score obtained by the students was 110.

Tabel 4. Results of Learning Motivation Students

\begin{tabular}{lcccccc}
\hline \multicolumn{1}{c}{ Classification } & & \multirow{2}{*}{$\%$} & \multirow{2}{*}{ Min } & \multirow{2}{*}{ Max } & \multirow{2}{*}{ Mean } \\
\hline $45,0-81,0$ & Category & Freq & & & & \\
$82,0-117,0$ & Very not good & 0 & 0 & & & \\
$118,0-153,0$ & Not good & 1 & 0.6 & & & \\
$154,0-189,0$ & Enough & 5 & 2.9 & \multirow{2}{*}{93} & 209 & \multirow{2}{*}{156.32} \\
$190,0-225,0$ & Good & 109 & 62.6 & & & \\
\hline
\end{tabular}

Based on Table 4 it is known that as many as $62.6 \%$ (109 of 174) students are in the good category with the maximum score of all statements on the learning motivation variable is 209 and the minimum score is 93. This shows that most students admit that there is good learning motivation after the implementation of the full system. day school. Furthermore, $33.9 \%$ (59 out of 175) students were in the very good category. This means that the implementation of the full day school system provides excellent benefits for students in fostering student motivation. Then there were $2.9 \%$ (5 of 174) students who were categorized as sufficient, which means that students were still confused about the role of the full day school system in increasing their learning motivation. Meanwhile, $0.6 \%$ (1 in 174) of students were categorized as poor, this shows that students thought that the implementation of the full day school system did not increase their learning motivation. The summary model is used to determine the percentage contribution of the influence given by variable $X$ to variable $Y$. Data analysis result shows that the value of $R$ Square is 0.613 or equal to $61.3 \%$. This states that the contribution of the influence of variable $X$ (Full Day School) to variable $Y$ (Motivation) is $61.3 \%$ while the remaining $39.7 \%$ is influenced by other factors that are not examined in this study, hereinafter referred to as variable intervening.

Tabel 5. Simple Linear Regression Test Results on ANOVA

\begin{tabular}{|c|c|c|c|c|c|c|}
\hline \multicolumn{7}{|c|}{ ANOVA $^{a}$} \\
\hline Model & & $\begin{array}{l}\text { Sum of } \\
\text { Squares }\end{array}$ & df & $\begin{array}{l}\text { Mean } \\
\text { Square }\end{array}$ & $\mathbf{F}$ & Sig. \\
\hline 1 & $\begin{array}{l}\text { Regression } \\
\text { Residual } \\
\text { Total }\end{array}$ & $\begin{array}{r}4423.841 \\
22330.687 \\
26754.529\end{array}$ & $\begin{array}{r}1 \\
172 \\
173\end{array}$ & $\begin{array}{r}4423.841 \\
129.830\end{array}$ & 34.074 & $0.000^{b}$ \\
\hline
\end{tabular}

ANOVA table is used to determine whether there is an effect of the implementation of full day school on the learning motivation of elementary school students. Table 5 shows that there is a significant effect on variable $X$ (implementation of full day school) on variable $Y$ (motivation). This is evidenced by the significance value of 0.000 which has met the requirements $<0.05$. The coefficients table is used to construct the regression equation, namely $\mathrm{Y}=\mathrm{a}+\mathrm{bx}$. Based on the data analysis result, the regression equation is obtained, namely $\mathrm{Y}=36.206+0.311 \mathrm{x}$. The value of a (constant) positive shows a positive influence on the variable of full day school implementation on learning motivation of elementary school students. From this equation shows that the variable implementation of full day school has a 
positive effect as well. This means that if there is an addition of one value in the variable implementation of full day school will increase the value of the motivation variable. The determination of the hypothesis in this study can also be seen from the calculation of the $t$ test or comparing the t-count and t-table values. The t-test is also used to see the effect of variable $X$ on variable $Y$ so that researchers can take hypotheses from the study. The result of $t$-test calculation shows that $t$ count is greater than $t$ table $(5.837>1.65366)$, so it can be concluded that $\mathrm{Ha}$ is accepted (there is an effect of full day school implementation on student learning motivation).

\section{Discussion}

\section{Impelementation of Full Day School}

The results of the learning motivation of elementary school students 47 / IV of Jambi City were measured using a motivation questionnaire which consists of 30 statements with 5 indicators. Based on the results of descriptive statistical analysis, it shows that the implementation of full day school in state elementary schools 47 / IV Jambi City is in the good category as much as $73 \%$ with 127 respondents in the good category from the total number of respondents as many as 174 respondents. This is also supported by the results of interviews the researchers have conducted. Based on the results of interviews that have been carried out, it is known that the implementation of the full day school system at State Elementary School 47 / IV in Jambi City has been sufficiently ongoing and has been implemented in all classes from grade I to grade VI. In its implementation at 47 / IV Elementary Schools in Jambi City, the application of this school system is almost the same as schools in general, but to start teaching and learning activities starting from 07.00 to $14: 15$ which includes a TPA schedule at the end of each lesson and extracurricular activities, as well as schools. This has integrated general education and religious education into one curriculum fabric and also in developing the creativity of students.

Elementary School 47 / IV of Jambi City implements a full day school system which aims to maximize the time students have so that the time they have can be fully used for learning, extracurricular activities and shaping the character of students. No time is wasted just playing around after school. With this full day school, students make more use of their free time for positive things and are related to their duties because the time is wasted and just for playing it is very useful to support learning material at school. The amount of material presented also gives reasons why the implementation of full day school, which is basically the implementation of learning in ordinary schools and what is done in full day schools is no different. The only difference lies in the selection of learning methods that can avoid the boredom and burnout of students because the full day school is tired both physically and psychologically (Maison et al., 2020). The implementation of learning in a full day school is the process of teaching and learning in class and is the core of all school activities, so the implementation of learning is the interaction that occurs from teachers and students in the context of delivering learning to students so that the teaching objectives can be achieved.

In the learning implementation function, it contains organizational activities or learning leadership that must be carried out by teachers and students during the learning process. During the first learning process, the teacher must prepare preliminary activities, namely preparing students physically and psychologically to be ready to take part in learning, asking questions related to previous learning with the material to be studied, explaining learning objectives, basic competencies that students must master. The second is the core activity which is a learning process to achieve basic competencies that are carried out actively, fun, challenging, creativity, and independence of students (Asrial et al., 2020; Tanti et al., 2021). And the last one is the closing activity, namely the teacher and students together to make a summary or conclusion of the material that has been studied, conduct an assessment or reflection on the activities that have been carried out, plan follow-up activities, presenting programs, and convey learning plans to be studied next.

The significant impact on State Elementary School 47 / IV Jambi City was expressed by Mr. Ansori, S.Pd., M.Pd as the Principal of Elementary School 47 / IV of Jambi City, who revealed that: "The impact of full day This school has the first negative impact, many parents 
are worried because the facilities at this school are lacking. The full day school program must have facilities and infrastructure, the other is because food is not monitored and the children at the last hour become lethargic maybe because their snacks have run out or Parents do not deliver their lunch and children do not concentrate on their studies, then the positive impact is we can see the creativity of children and children are fresher due to the two-day holiday, in terms of achievement because there are extracurricular activities that become even more stable".

The same thing was also expressed by the classroom teacher who stated that: "The negative impact of implementing this full day school is that students are tired, so it is indeed quite a long time at school that is quite draining. For the positive impact, the character value is easier to apply because of the long time then the teacher is more free to deliver the material and the child also gets more time input in extracurricular activities and also increases the child's achievement. Based on the results of descriptive statistical analysis and the results of the above interviews, it can be concluded that the implementation of full day school in the implementation of learning that occurs in 47 / IV Elementary Schools in Jambi City is already in a good category. With the implementation of the full day school system, it has a positive impact, namely that the creativity of students can be further developed, achievement increases, and students can develop their talents and skills through extracurricular activities, then it is easier for teachers to deliver material to students because of the long time it takes to the negative impact of students experiencing fatigue, lethargy and no longer enthusiastic in participating in learning (Astalini et al., 2020; Darmaji et al., 2020).

\section{Learning Motivation}

The results of the learning motivation of elementary school students 47 / IV of Jambi City were measured using a motivation questionnaire adapted from (Aryani, 2018) which consists of 45 statements with 3 indicators. Based on the results of descriptive statistical analysis, it shows that the learning motivation of state elementary school students 47 / IV Jambi City is in the good category as much as $62.6 \%$ with 109 respondents in the good category from the total number of respondents as many as 174 respondents. This is also supported by the results of interviews the researchers have conducted. Based on the interviews that have been carried out, it is known that students are always present in participating in learning activities because of the desire and desire to learn in class. In addition, students also said that the methods used by the teacher in teaching also motivated them to participate in learning activities.

Occasionally students are invited to leave the classroom to immediately see the situation around them so that students do not feel bored learning in class. Then in learning activities the teacher does not focus only on the cermah method, but the teacher invites students to interact actively by holding discussions and dialogues and by interspersing learning activities by giving a little game. However, the motivation and need for learning is still lacking. This is indicated by students who rarely repeat lessons at home. Therefore, the teacher gives assignments so that they can learn independently. Then in order to increase the learning motivation of students, the teacher also gives awards or praise to students in the teaching and learning process (Tanti, Kurniawan, Kuswanto, et al., 2020). The teacher also gives responsibility to those who are diligent because by giving responsibility students will feel that they are trusted so that they can increase students' self-confidence. Furthermore, students also expressed that they were comfortable learning in class and felt comfortable with the school environment. So that this causes the learning motivation of students to be good. However, there were students who expressed that the long study time from morning to evening caused students to become bored and wanted to go home quickly (Maison. et al., 2019). Growing learning motivation in each student is a good thing because learning motivation can function to encourage behavior or an action (Maison et al., 2020; Tanti, Kurniawan, Kuswanto, et al., 2020). Without motivation, there will be no action such as learning; motivation serves as a direction. This means directing the action towards achieving the desired goal. Motivation serves as a driving force. It functions as an engine for the car. The size of the motivation will determine fast or slow a job. 


\section{The effect of full day school implementation on student learning motivation.}

Hypothesis testing shows that there is a significant influence between the implementation of full day school on student learning motivation. This can be seen from the results of the simple linear regression calculation $Y=a+b x$, the simple linear regression equation is $Y=36.206+0.311 x$. from the equation it appears that the coefficients are positive. This shows that $Y$ changes with the direction of $X$. so the value of $Y$ decreases as $X$ decreases. So it can be concluded that the full day school system will improve, so students' learning motivation will also increase and vice versa. This equation means that every time $X$ increase by 1 , the $Y$ average increases by 36,206 . Based on the research results, it can be argued that the hypothesis in this study that "there is an influence between the application of full day school to student learning motivation" can be accepted significantly.

Relevant research that supports this hypothesis is research results show that there is an influence between the implementation of a full day school management system on student learning motivation (Rosalina, 2012; Wahyuni et al., 2018). The full day school program is an alternative to the moral decline that occurs in students (Ningsih \& Sugiaryo., 2016). In addition, the application of the full day school system is to minimize the various problems that exist in the community which are currently increasingly troubling parents and expect their children to get the best education, both from academic and non-academic aspects and to provide protection for their children from unfavorable and unhealthy environments. and free association (M. Astuti, 2013). Learning designed in full day svhool schools is also made more enjoyable so that students don't get bored easily and the arrangement of classrooms and the school environment is also a concern of the school so that students are comfortable in following the learning process. This decision is the main focus for designing student learning environments so that students are more productive and learning is more effective (Smith, 2013; Tanti, Kurniawan, Wirman, et al., 2020).

One of the goals of the full day school program is that the development of student interests, talents and intelligence is monitored from an early age through the guidance and counseling program provided by the school (Siregar, 2017). This guidance and counseling is carried out by the teacher himself so that the teacher is obliged to provide motivation to the students. This motivation is needed for students because motivation is the overall driving force that is in students to foster learning activities and leads students to be encouraged to do something to achieve certain goals (Tanti, Kurniawan, \& Ningsi, 2020; Tasrim \& Elihami, 2020). Motivated student behavior is shown by behavior that is full of energy, directed and long-lasting (J. Astuti et al., 2020).

\section{Conclusions and Suggestions}

Based on the results of the research that has been done, it can be concluded that the implementation of full day and student motivation in Elementary School 47 / IV Jambi City is already in a good category. This is reinforced by the results of interviews which show that through the implementation of full day school it can have a positive impact, namely that student creativity can be more developed, achievement increases, and students can develop their talents and skills through extracurricular activities, which can then be developed. Make it easier for teachers to deliver material to students because of the time. which is old. Based on the hypothesis test, it is known that there is a significant influence between the implementation of full day school and students' learning motivation in elementary schools.

\section{References}

Al-Qurni, W. (2019). Pengaruh Pelaksanaan Ful Day School Terhadap Interaksi Sosial dan Sosialisasi Anak di Lingkungan Masyarakat (Studi Kasus Di MTs Attaqwa 10 Terpadu Bekasi). Universitas Islam Negeri (UIN) Syarif Hidayatullah.

Albrecht, J. R., \& Karabenick, S. A. (2018). Relevance For Learning And Motivation In Education. The Journal Of Experimental Education, 86(1), 1-10. https://doi.org/10.1080/00220973.2017.1380593. 
Antara, I. G. W. S., Sudarma, I. K., \& Dibia, I. K. (2020). The Assessment Instrument of Mathematics Learning Outcomes Based on HOTS Toward Two-Dimensional Geometry Topic. Indonesian Journal Of Educational Research and Review, 3(2), 1924. https://doi.org/ijerr.v3i2.25869.g15588.

Aryani, A. N. (2019). Pengaruh Motivasi Belajar Peserta Didik Terhadap Sistem Full Day School. Universitas Negeri Jakarta.

Asrial., Syahrial., Kurniawan, D. A., Chan, F., Septianingsih, R., \& Perdana, R. (2019). Multimedia innovation 4.0 in education: E-Modul Ethnoconstructivism. Universal Journal of Educational Research, 7(10), 2098-2107. https://doi.org/10.13189/ujer.2019.071007.

Asrial, A., Syahrial, S., Maison, M., Kurniawan, D. A., \& Piyana, S. O. (2020). Ethnoconstructivism E-Module to Improve Perception, Interest, And Motivation of Students in Class V Elementary School. JPI (Jurnal Pendidikan Indonesia), 9(1), 3041. https://doi.org/10.23887/jpi-undiksha.v9i1.19222.

Astalini., Kurniawan, D. A., Perdana, R., \& Kurniawan, W. (2019). Identification Attitudes of Learners on Physics Subjects. Journal of Educational Science and Technology, 5(1), 39-48. https://doi.org/10.26858/est.v5i1.8231.

Astalini, A., Darmaji, D., Kurniawan, D. A., Anggraini, L., \& Perdana, R. (2020). EAssessment on Student's Self-Concept for Physics Learning. Jurnal Ilmu Pendidikan, 25(2), 73-81. http://dx.doi.org/10.17977/um048v25i2p73-81.

Astuti, J., Novita, M., \& S., I. M. (2020). Peningkatan Motivasi Belajar Menggunakan Contextual Teaching And Learning Di Madrasah Ibtidaiyah Swasta Raudhatul Mujawwidin Tebo. JURNAL EDUCATIVE, Journal Of Education Studies, 5(1), 16-28. http://dx.doi.org/10.30983/educative.v5i1.1630.

Astuti, M. (2013). Implementasi Program Full Day School Sebagai Usaha Mendorong Perkembangan Sosial Peserta Didik TK Unggulan Al-Ya'lu Kota Malang. Jurnal Kebijakan Dan Pengembangan Pendidikan, 1(2), 133-140. https://doi.org/10.22219/jkpp.v1i2.1561.

Budiarati, R. S., \& Sadikin, A. (2015). Pengaruh Kwartet Animalia Dengan Model TGT Terhadap Pemahaman Materi Taksonomi Hewan Siswa SMAN 8 Kota Jambi. Jurnal Biodik, 1(1), 1-9.

Cresswell, J. W. (2012). Educational Research. Pearson.

Darmaji., Kurniawan, D. A., Parasdila, H., \& Irdianti. (2018). Description Of Science Process Skills' Physics Education Students At Jambi University In Temperature And Heat Materials. The Education Review, 2(9), 485-498. https://doi.org/10.26855/er.2018.09.005.

Darmaji, D., Astalini, A., Kurniawan, D. A., N., Ingsi, A. P., Romadona, D. D., \& Dari, R. W. (2020). Regression of Science Process Skills On Critical Thinking Skills In Two Junior High Schools In Jambi City. JIPF (Jurnal IImu Pendidikan Fisika), 5(3), 177-186. https://doi.org/10.26737/jipf.v5i3.1788.

Darussyamsu, R., Wahyuni, R., Fitri, R., Fadilah, M., Putri, D. H., \& Mukhtar, M. (2019). Senior High School Biology Teachers' Perception Towards Evolution Learning. Jurnal Pembelajara Dan Penelitian IPA, 5(2), 185-201. http://dx.doi.org/10.30870/jppi.v5i2.3335.

Fujika, A., Anggreini, E., \& Budiarti, R. S. (2015). Analisis Kemampuan Berfikir Kritis Siswa SMAN 5 Kota Jambi Melalui Pembelajaran Berbasis Masalah Pada Konsep Pencemaran Lingkungan. Jurnal Biodik, 1(1), 1-10.

Gopalan, V., Bakar, J. A. A., Zulkifli, N. A., Alwi, A., \& Mat, R. C. (2017). A Review Of The Motivation Theories In Learning. AIP Conference Procidings. https://doi.org/10.1063/1.5005376.

Ibrahim, M. M., \& Nat, M. (2019). Blended learning motivation model for instructors in higher education institutions. International Journal of Educational Technology in Higher Education, 16(12), 7-25. https://doi.org/10.1186/s41239-019-0145-2.

Ifinedo, P. (2016). Examing Students' Intention To Continue Using Blogs For Learning: Perspectives From Technology Acceptece, Motivational, And Social-Cognitive 
$\begin{array}{lllll}\text { Frameworks. } \quad \text { In } & \text { Computers }\end{array}$ http://doi.org/10.1016/J.chb.2016.12.049.

Islami, R. A. Z. E., Nahadi., \& Permanasari, A. (2015). Hubungan Literasi Sains Dan Kepercayaam Diri Siswa Pada Konsep Asam Basa. Jurnal Penelitian Dan Pembelajaran IPA, 1(1), 16-25. http://dx.doi.org/10.30870/jppi.v1i1.324.

Khan, T., Johnston, K., \& Ophof, J. (2019). The Impact Of An Augmented Reality Application On Learning Motivation Of Students. Advances Human-Computer Interaction. https://doi.org/10.1155/2019/7208494.

König, J., Jäger-Biela, D. J., \& Glutsch, N. (2020). Adapting to online teaching during COVID19 school closure: teacher education and teacher competence effects among early career teachers in Germany. European Journal of Teacher Education, 43(4), 608622. https://doi.org/10.1080/02619768.2020.1809650.

Maison., Astalini., Kurniawan, D. A., Perdana, R., \& Anggraini, L. (2019). The Phenomenon of Physicology Senior High School Education: Relationship of Students' Attitudes towards Physics, Learning Style, Motivation. Universal Journal of Educational Research, 7(10), 2199-2207. https://doi.org/10.13189/ujer.2019.071018.

Maison, M., Kurniawan, D. A., \& Pratiwi, N. I. S. (2020). Pendidikan sains di sekolah menengah pertama perkotaan: Bagaimana sikap dan keaktifan belajar siswa terhadap sains? Jurnal Inovasi Pendidikan IPA, 6(2). https://doi.org/10.21831/jipi.v6i2.32425.

Moozeh, K., Farmer, J., Tihanyi, D., Nadar, T., \& Evans, G. J. (2019). A Prelaboratory Framework Toward Integrating Theory And Utility Value With Laboratories: Student Perceptions On Learning And Motivation. Journal of Chemical Education, 3(1), 1-10. https://doi.org/10.1021/acs.jchemed.9b00107.

Ningsih, S., \& Sugiaryo. (2016). Hubungan Pelaksanaan Full Day School Dan Boarding School Dengan Pembentukan Karakter Pada Siswa Kelas XI MAN 1 Surakarta Tahun 2016/2017. Global Citizen, 2(2), 53-64. https://doi.org/10.33061/glcz.v2i2.1565.

Puspitarini, Y. D., \& Hanif, M. (2017). Using learning media to inrease learning motivation in elementary school. Anatolian Journal of Education, 4(2), 53-60. https://doi.org/10.29333/aje.2019.426a.

Riswanto, A., \& Aryani, S. (2017). Learning motivation and student achievment: description analysis and relationships both. COUNS-EDU: The International Journal of Counseling and Education, 12(7), 42-47. https://doi.org/10.23916/002017026010.

Rosalina, T. (2012). Pengaruh Manajemen Pembelaaran Full Day School Terhadap Motivasi Belajar Siswa. Jurnal Manajemen Pendidikan, 23(5), 434-438.

Ryan, R. M., \& Deci, E. L. (2020). Intrinsic And Exrinsic Motivation From A SelfDetermination Theory Perspective: Definitions, Theory, Practice, And Future Directions. Contemporary Education Psychology, 30(1), 1-11. https://doi.org/10.1016/j.cedpsych.2020.101860.

Sari, P. R., Wardani, D. K., \& Noviani, L. (2017). Implementasi full day school (sekolah sehari penuh) sebagai best practice (latihan terbaik) dalam pendidikan karakter di SMA Negeri 1 Sragen. BISE:Jurnal Pendidikan Bisnis Dan Ekonomi, 3(2), 1-16.

Siregar, L. Y. S. (2017). Full Day School Berbasis Al-Qur'an (Suatu Tinjauan Psikologi Pendidikan Islam). FIKROTUNA, Jurnal Pendidikan Dan Manajemen Islam, 5(1), 120. https://doi.org/10.32806/jf.v5i1.2945.

Smith, T. J. (2013). Design Learning Evironments To Promote Student Learning: Ergonomics In All But Name. Work, 4(4), 39-60. http://doi.org/10.3233/WOR-121493.

Soapatty, L. (2014). Pengaruh Sistem Sekolah Sehari Penuh (Full Day School) Terhadap Prestasi Akademik Siswa SMP Jati Agung Sidoarjo. Kajian Moral Dan Kewarganegaraan, 2(2), 719-733.

Sunaryo. (2014). Psikologi Untuk Keperawatan. Penerbit Buku Kedokteran.

Tanti, T., Kurniawan, D. A., Kuswanto, K., Utami, W., \& Wardhana, I. (2020). Science Process Skills and Critical Thinking in Science: Urban and Rural Disparity. Jurnal Pendidikan IPA Indonesia, 9(4), 489-498. http://doi.org/10.15294/jpii.v9i4.24139. 
Tanti, T., Kurniawan, D. A., \& Ningsi, A. P. (2020). Description of students' science process skills on density material. Jurnal Inovasi Pendidikan IPA, 6(2). http://doi.org/10.21831/pep.v24i1.31194.

Tanti, T., Kurniawan, D. A., Sukarni, W., Erika, E., \& Hoyi, R. (2021). Description of Student Responses Toward the Implementation of Problem-Based Learning Model in Physics Learning. JIPF (Jurnal IImu Pendidikan Fisika), 6(1), 30-38. http://doi.org/10.26737/jipf.v6i1.1787.

Tanti, T., Kurniawan, D. A., Wirman, R. P., Dari, R. W., \& Yuhanis, E. (2020). Description of student science process skills on temperature and heat practicum. Jurnal Penelitian Dan Evaluasi Pendidikan, 24(1). https://doi.org/10.21831/pep.v24i1.31194.

Tasrim, T., \& Elihami, E. (2020). Motivasi Kerja Pendidik Dalam Meningkatkan Manajemen Lembaga Pendidikan Dasar. MAHAGURU: Jurnal Pendidikan Guru Sekolah Dasar, 1(1), 48-53.

Wahyuni, P. D., Djatmika, E. T., \& As'sari, A. R. (2018). Pengaruh Full Day School dan Gerakan Literasi Sekolah terhadap Hasil Belajar dengan Mediasi Motivasi Belajar. Jurnal Pendidikan, 3(5), 679-684. https://doi.org/10.17977/jptpp.v3i5.11096.

Wardani, A. D., Gunawan, I., Kusumaningrum, D. E., Benty, D. D. N., Sumarsono, R. B., Nurabadi, A., \& Handayani, L. (2020). Student learning motivation: a conceptual paper. 2nd Early Childhood and Primary Childhood Education (ECPE 2020), 275278. https://doi.org/10.2991/assehr.k.201112.049. 